Jurnal Keperawatan Silampari

Volume 4, Nomor 1, Desember 2020

e-ISSN: 2581-1975

p-ISSN: 2597-7482

DOI: https://doi.org/10.31539/jks.v4i1.1587

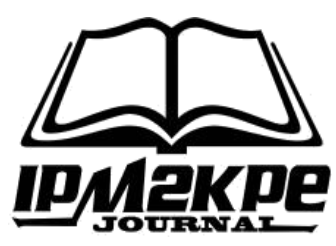

\title{
ANALISIS FAKTOR RISIKO KEMATIAN DENGAN PENYAKIT KOMORBID COVID-19
}

\author{
Raden Muhammad Ali Satria ${ }^{1}$, Resty Varia Tutupoho ${ }^{2}$, Djazuly Chalidyanto ${ }^{3}$ \\ Universitas Airlangga ${ }^{1,2,3}$ \\ radenj@gmail.com ${ }^{1}$
}

\begin{abstract}
ABSTRAK
Tujuan penelitian ini adalah untuk menganalisis penyakit komorbid sebagai faktor risiko kematian akibat COVID-19 di RS Bhakti Dharma Husada Surabaya. Metode penelitian ini adalah penelitian analitik observasional dengan desain studi retrospektif. Hasil penelitian menunjukkan bahwa 358 pasien terinfeksi COVID-19 dan dikonfirmasi dengan usap hidung dan/atau tenggorokan. 66 pasien (18\%) meninggal karena COVID-19. 60,6\% berjenis kelamin laki-laki (OR 1,87, P 0,041), 22,7\% berusia> 64 tahun (OR 2,097, P 0,041), dan 83,3\% diantaranya merupakan faktor risiko penyerta. Diabetes melitus $(30,3 \%)$ (OR 4,348, P 0,000), dan penyakit kardiovaskular (10,6\%) (OR 4,319, P 0,016) merupakan faktor risiko kematian tertinggi pada COVID-19. Simpulan, Laki-laki, usia lanjut, diabetes, dan hipertensi merupakan faktor risiko kematian pada COVID-19.
\end{abstract}

Kata Kunci: COVID-19, Diabetes, Hipertensi, Komorbid, Lansia, Mortalitas

\section{ABSTRACT}

The purpose of this study was to analyze comorbid diseases as a risk factor for death due to COVID-19 at Bhakti Dharma Husada Hospital Surabaya. The research method was an observational analytic study with a retrospective research design. The results showed that 358 patients were infected with COVID-19 and confirmed with nose and / or throat swabs. 66 patients (18\%) died from COVID-19. 60.6\% were male (OR 1.87, P 0.041), 22.7\% aged $>64$ years (OR 2.097, P 0.041), and 83.3\% were co-risk factors. Diabetes mellitus (30.3\%) (OR 4,348, P 0,000), and cardiovascular disease (10.6\%) (OR 4,319, P 0.016) were the highest risk factors for death in COVID-19. Conclusion: Men, old age, diabetes, and hypertension are risk factors for death in COVID-19.

Keywords: COVID-19, Diabetes, Hypertension, Comorbid, Elderly, Mortality

\section{PENDAHULUAN}

Penyakit coronavirus 2019 (COVID-19) merupakan perhatian kesehatan yang besar saat ini, terutama untuk lanjut usia. COVID-19 merupakan penyakit yang diakibatkan virus SARS-CoV-2. Wabah pneumonia virus yang tidak diketahui dengan etiologinya pertama kali diperkenalkan di Wuhan, Cina pada 12 Desember 2019 (Ji et al., 2020). Penelitian lebih lanjut mengindikasikan adanya coronavirus baru yang cepat terisolasi, dan 
genomenya telah berlanjut (Chan et al., 2020). World Health Organization (WHO) menamakan virus ini sebagai 2019 novel coronavirus (2019-nCoV) (Zhu et al., 2020) dan namanya berganti Severe Acute Respiratory Syndrome Coronavirus-2 (SARS-CoV-2) oleh Coronaviridae Study Group (CSG) dari International Committee on Taxonomy of Viruses. Secara resmi, COVID-19 menjadi nama dari penyakit yang diakibatkan virus tersebut (Gorbalenya et al., 2020).

Covid-19 merupakan jenis virus baru yang ditemukan pada tahun 2019 dan belum diidentifikasi menyerang manusia sebelumnya (Zulva, 2019). Covid-19 merupakan penyakit menular yang disebabkan oleh sindrom pernapasan akut coronavirus 2 (severe acute respiratory syndrome coronavirus 2 atau SARS-CoV02) (Setiawan, 2020). WHO menetapkan virus Corona sebagai pandemi pada 11 maret 2020 karena penularan virus ini sangat cepat (Moana, 2020).

SARS-CoV-2 dimulai dari pasar makanan laut lokal di Wuhan yang kemungkinan berasal dari kelelawar, karena 96\% secara genom mirip dengan coronavirus kelelawar (BatCoV RaTG13) dan infeksinya menjadi sulit dikendalikan atau dicegah karena otoritas kesehatan Cina mengatakan kemungkinan transmisi manusia ke manusia meskipun asimtomatis (Fang et al., 2020).

Penyakit kronik jantung dan metabolik, adanya peradangan akut dan penurunan fungsi organ (jantung, ginjal, hati, dan hematologi) yang dialami pasien diawal perawatan dapat meningkatkan risiko kematian karena infeksi COVID-19 (Yang \& Yan, 2020).

Indikasi rawat inap di rumah sakit pasien COVID-19 sulit untuk disamakan karena tergantung pada prevalensi pengujian komunitas dan kriteria penerimaan, yang bervariasi di setiap negara. Namun, diperkirakan 1 dari 5-10 orang dewasa memiliki penyakit dengan tingkat keparahan dan memiliki kriteria cukup untuk dirawat di rumah sakit. Sebagian besar pasien dirawat dengan infeksi pernapasan akut yang parah atau sindrom pernapasan akut yang parah menurut definisi kasus WHO. Kriteria perawatan di ruang intensif juga bervariasi di setiap negara. Usia tua, penyakit kronis, dan jenis kelamin pria secara konsisten dikaitkan dengan peningkatan mortalitas (Docherty et al., 2020).

RSUD Bhakti Dharma Husada (BDH) Surabaya adalah salah satu rumah sakit milik pemerintah kota Surabaya yang memberikan layanan pada pasien COVID-19. RSUD BDH Surabaya mulai melayani pasien COVID-19 pada bulan Maret 2019. Adanya pasien COVID-19 yang meninggal dunia di RSUD BDH Surabaya yang memiliki komorbid Diabetes Mellitus, kardiovaskular, hematologi, usia tua, Penyakit paru kronik, CVA, CKD, dan TB sehingga peneliti ingin mengetahui faktor-faktor resiko pasien meninggal.

\section{METODE PENELITIAN}

Penelitian ini adalah penelitian analitik observasional dengan desain studi retrospektif untuk mengetahui faktor risiko mortalitas pasien COVID-19. Populasi penelitian adalah pasien COVID-19 yang rawat inap di RSUD Bhakti Dharma Husada Surabaya sejak 1 maret-21 juli 2020. Sampel penelitian diambil secara total dari pasien rawat inap konfirm Covid-19 yang meninggal dunia dan tidak meninggal dunia di RSUD Bhakti Dharma Husada Surabaya. Kriteria inklusi penelitian ini adalah: pasien Covid-19 yang rawat inap, usia > 18 tahun, dan terkonfirmasi Covid-19. Kriteria eksklusi penelitian ini adalah: data demografi dan komorbid pasien yang tidak lengkap . 
Penelitian ini dimulai dari pemilihan sampel, yaitu semua pasien Covid-19 yang rawat inap. Sampel diambil dari subyek yang datang di Instalasi Rawat Inap Covid-19 RSUD Bhakti Dharma Husada Surabaya. Total sampel yang didapat sejumlah 358, tetapi yang memenuhi kriteria inklusi penelitian hanya sejumlah 253 sampel. Subyek yang sudah memenuhi kriteria inklusi dilakukan pengambilan sampel.

\section{HASIL PENELITIAN}

Tabel. 1

Demografi dan Komorbid

Pasien Covid-19 ( $=253)$

\begin{tabular}{lc}
\hline Faktor Risiko & $\mathrm{N}(\%)$ \\
\hline Usia & $51.00(20-95)^{*}$ \\
$>64$ tahun & $38(15)$ \\
$19-65$ tahun & $215(85)$ \\
\hline Jenis Kelamin & \\
Laki-laki & $126(49.8)$ \\
Perempuan & $127(50.2)$ \\
\hline Komorbid & \\
Diabetes & $37(14.62)$ \\
Hipertensi & $11(4.34)$ \\
TB & $3(1.18)$ \\
PPOK & $4(1.58)$ \\
Jantung & $12(4.74)$ \\
CKD & $2(0.79)$ \\
CVA & $4(1.58)$ \\
Hamil & $6(2.37)$ \\
Asma & $1(0.39)$ \\
HIV/AIDS & $2(0.79)$ \\
Sumber data : Tahun 2020 &
\end{tabular}

Berdasarkan tabel 1 menunjukkan bahwa rata-rata usia pasien yang diamati adalah 51 tahun dengan usia minimal 20 tahun dan maximal 95 tahun. Pasien dengan usia $>64$ tahun sejumlah 38 (15\%) dan usia 19-65 tahun sejumlah 215 (85\%). Jenis kelamin yang diamati, laki-laki 126 (49.8\%) dan perempuan 127 (50.2\%). Dari data demografi diatas data faktor risiko komorbid yang diamati adalah diabetes, hipertensi, TB, PPOK, jantung, CKD, CVA, hamil, asma, HIV/AIDS. Pasien komorbid yang diamati dapat memiliki lebih dari satu komorbid. Pasien yang memiliki komorbid rata-rata di usia $>45$ tahun. Dari data pasien Covid-19 yang diamati $66(26.08 \%)$ pasien meninggal. Dua penyakit komorbid yang dimiliki pasien terbanyak adalah diabetes dan jantung. 
Tabel. 2

Faktor Risiko Meninggal Berdasarkan Usia dan Jenis Kelamin Pasien Covid-19 (N=253)

\begin{tabular}{lccccc}
\hline \multicolumn{1}{c}{ Variable } & Pengamatan & $\begin{array}{c}\text { Meninggal } \\
(\%)\end{array}$ & $\begin{array}{c}\text { Tidak Meninggal } \\
(\%)\end{array}$ & OR (95\% CI) & P-value \\
\hline Usia & & & & & \\
$>64$ tahun & 38 & $15(22.7)$ & $23(12.3)$ & $\begin{array}{c}2.097(1.018- \\
4.319)\end{array}$ & 0.041 \\
19-64 tahun & 215 & $51(77.3)$ & $164(87.7)$ & & \\
\hline Jenis Kelamin & & & & & \\
Laki-laki & 126 & $40(60.6)$ & $86(46.0)$ & $1.807(1.020-$ & 0.041 \\
Perempuan & 127 & $26(39.4)$ & $1014.0)$ & $3.199)$ & \\
\hline
\end{tabular}

Berdasarkan tabel 2 menunjukkan bahwa pasien usia > 64 tahun memiliki risiko 2.097 kali lebih besar meninggal karena Covid-19, dengan P 0.041. Pasien jenis kelamin laki-laki memiliki risiko meninggal 1.087 kali lebih besar dari perempuan, dengan $\mathrm{P} 0.041$.

Tabel. 3

Faktor Risiko Meninggal Berdasarkan Komorbid Pasien Covid-19 ( $\mathrm{N}=253)$

\begin{tabular}{|c|c|c|c|c|c|c|c|}
\hline \multirow{2}{*}{ Variabel } & \multirow{2}{*}{ Pengamatan } & \multicolumn{2}{|c|}{ Meninggal } & \multicolumn{2}{|c|}{ Tidak Meninggal } & \multirow[t]{2}{*}{ OR $(95 \%$ CI $)$} & \multirow[t]{2}{*}{ P-value } \\
\hline & & $\mathrm{Ya}(\%)$ & Tidak (\%) & Ya (\%) & Tidak (\%) & & \\
\hline Diabetes & 37 & $\begin{array}{c}20 \\
(30.3)\end{array}$ & $46(69.7)$ & $17(9.1)$ & 170 (90.9) & $\begin{array}{r}4.384(2.108- \\
8.968) \\
1.659(0.470-\end{array}$ & 0.000 \\
\hline Hipertensi & 11 & $4(6.1)$ & $62(93.3)$ & $7(3.7)$ & $180(96.3)$ & $\begin{array}{r}5.860) \\
5.813(0.518-\end{array}$ & 0.427 \\
\hline TB & 3 & $2(3.0)$ & $64(97.0)$ & $1(0.5)$ & $186(99.5)$ & $\begin{array}{r}65.184) \\
2.891(0.399-\end{array}$ & 0.107 \\
\hline PPOK & 4 & $2(3.0)$ & $64(97.0)$ & $2(1.1)$ & 185 (98.9) & $\begin{array}{r}20.946) \\
4.319(1.321-\end{array}$ & 0.272 \\
\hline Jantung & 12 & $7(10.6)$ & $59(89.4)$ & $5(2.7)$ & $182(97.3)$ & $\begin{array}{r}14.119) \\
2.862(0.176-\end{array}$ & 0.009 \\
\hline CKD & 2 & $1(1.5)$ & $65(98.5)$ & $1(0.5)$ & $186(99.5)$ & $\begin{array}{r}46.410) \\
2.891(0.399-\end{array}$ & 0.439 \\
\hline CVA & 4 & $2(3.0)$ & $64(97.0)$ & $2(1.1)$ & 185 (98.9) & 20.946) & 0.272 \\
\hline Hamil & 6 & $0(0.0)$ & $66(100.0)$ & $6(3.2)$ & $181(96.8)$ & - & 0.141 \\
\hline Asma & 1 & $0(0.0)$ & $66(100.0)$ & $1(0.5)$ & $186(99.5)$ & - & 0.552 \\
\hline HIV/AIDS & 2 & $0(0.0)$ & $67(100.0)$ & $2(1.1)$ & $185(98.9)$ & - & 0.399 \\
\hline
\end{tabular}

Berdasarkan tabel 3 menunjukkan bahwa pasien dengan komorbid diabetes dan penyakit jantung menjadi faktor risiko kematian covid-19 di rsud bdh karena pasien dengan komorbid diabetes memiliki risiko 4.384 kali lebih besar meninggal karena Covid-19 dari pasien tanpa komorbid diabetes, dengan P 0.000 dan pasien dengan komorbid Jantung memiliki risiko 4.319 kali lebih besar meninggal karena Covid-19 dari pasien tanpa komorbid Jantung, dengan P 0.009. Sedangkan komorbid Hipertensi, TB, PPOK, CKD, 
CVA, Hamil, Asma, dan HIV/AIDS tidak menjadi faktor risiko kematian COVID-19 karena nilai $\mathrm{P}>0.05$.

\section{PEMBAHASAN}

Covid-19 merupakan masalah kesehatan yang dialami seluruh dunia. Dari data WHO bulan Desember 2019-23 Juli 2020 ada 15.012.731 orang telah terinfeksi Covid-19 dan 619.150 orang telah meninggal akibat Covid-19. Di Indonesia 89.869 orang telah terinfeksi Covid-19 dan 4.320 orang telah meninggal karena Covid-19. Surabaya merupakan salah satu kota dengan kasus Covid-19 terbanyak.

Saat ini, penyebaran SARS-CoV-2 dari manusia ke manusia menjadi sumber transmisi utama sehingga penyebaran menjadi lebih agresif. Transmisi SARS-CoV-2 dari pasien simptomatk terjadi melalui droplet yang keluar saat batuk atau bersin (Han \& Yang, 2020). Beberapa laporan kasus menunjukkan dugaan penularan dari karier asimtomatis, namun mekanisme pastinya belum diketahui. Kasus-kasus terkait transmisi dari karier asimtomatis umumnya memiliki riwayat kontak erat dengan pasien COVID-19 (Bai et al., 2020; Han \& Yang, 2020).

Karakteristik demografi usia dan jenis kelamin pada penelitian kami termasuk dalam faktor risiko kematian COVID-19, dimana usia dan jenis kelamin memiliki nilai $\mathrm{P}<0.05$. Hal ini sesuai dengan penelitian-penelitian sebelumnya. Faktor usia tampak merupakan faktor krusial bagi luaran COVID-19. Usia median pasien yang meninggal adalah 68 tahun dan merupakan usia yang lebih tua dari pasien yang sembuh secara signifikan. Lebih lanjut, 80\% kematian pada COVID-19 merupakan usia dewasa, yaitu 65 tahun, sehingga usia tua dapat dikatakan sebagai faktor risiko mortalitas COVID-19 (Chan et al., 2020; Zhu et al., 2020). Persentase angka kematian COVID-19 semakin meningkat karena penambahan usia, dengan pasien usia termuda 5\% sampai tertua 55\% (Zhou et al., 2020).

Jenis kelamin terbukti menjadi factor risiko mortalitas pada pasien COVID-19, dimana pria lebih banyak meninggal dibanding wanita. Hal ini dikarenakan adanya perbedaan mendasar dari sistem imunologi pria dan wanita, perbedaan pola hidup, dan prevalensi merokok (Wenham et al., 2020). Pria lebih sedikit yang sembuh dibandingkan kelompok yang meninggal. Angka kematian yang lebih tinggi dikaitkan dengan komorbiditas kronis yang lebih tinggi pada pria, misal penyakit kardiovaskular, hipertensi, penyakit paru, dan merokok (The Lancet, 2020).

Komorbid Diabetes dan penyakit Jantung yang diderita pasien Covid-19 dapat menjadi faktor risiko kematian pada penelitian kami karena $\mathrm{P}<0.05$. Hal ini sesuai dengan penelitian meta-analysis yang dilakukan (Mantovani et al., 2020) didapatkan prevalensi pasien diabetes yang rawat inap akibat COVID-19 sebesar 14,34\%, dimana pada pasien di negara Asia 11,06\%. Hal ini lebih rendah dari prevalensi di negara non Asia, yaitu 23,34\%. Pasien diabetes ini mempunyai risiko 2 kali lebih besar berkembang menjadi lebih berat atau penyakit kritis yang membutuhkan perawatan di ruang perawatan intensif (Longato et al., 2020; Wang et al., 2020). Pada rawat inap, pasien dengan diabetes mellitus tiga kali berisiko mengalami kematian akibat COVID-19. Diabetes mellitus merupakan faktor risiko bebas terhadap usia dan jenis kelamin.

Pasien COVID-19 dengan riwayat penyakit kardiovaskular atau penyakit paru obstruktif kronis (PPOK) mempunyai kecenderungan meninggal yang lebih tinggi (Aggarwal et al., 2020; Alharbi et al., 2020). Penyakit kronik jantung dan metabolik, 
adanya peradangan akut dan penurunan fungsi organ (jantung, ginjal, hati, dan hematologi) yang dialami pasien diawal perawatan dapat meningkatkan risiko kematian karena infeksi COVID-19 (Yang \& Yan, 2020).

Penelitian ini mempunyai kelemahan berupa jumlah populasi yang relatif sedikit dengan periode waktu yang singkat. Penelitian ini memiliki keterbatasan karena sifatnya yang retrospektif . Data yang diambil pada penelitian ini berjumlah 358, tetapi karena ada beberapa data yang tidak lengkap, hanya 253 yang memenuhi data pasien yang memenuhi syarat, sehingga semakin mengurangi jumlah data penelitian.

Pasien Covid-19 dengan faktor risiko kehamilan, Asma, HIV/AIDS yang diamati jumlahnya sedikit dan tidak meninggal, sehingga tidak dapat menjadi faktor risiko kematian. Faktor risiko kematian lainnya berupa Hipertensi, TB, PPOK, CKD, dan CVA tidak menjadi faktor risiko kematian karena jumlah kasus yang dilaporkan sedikit dengan nilai $\mathrm{P}>0.05$.

\section{SIMPULAN}

Laki-laki, usia lanjut, diabetes, dan hipertensi merupakan faktor risiko kematian pada COVID-19.

\section{SARAN}

Penyelidikan lebih lanjut diperlukan untuk menganalisis komorbid lain secara mendalam karena beberapa keterbatasan penelitian ini.

\section{DAFTAR PUSTAKA}

Aggarwal, G., Henry, B. ., Aggarwal, S., \& Bangalore, S. (2020). Cardiovascular Safety of Potential Drugs for the Treatment of Coronavirus Disease 2019. American Journal of Cardiology, 128 ,

$147-150$. https://auth.elsevier.com/ShibAuth/institutionLogin?entityID=https://idp.eng.nhs.uk/o penathens\&appReturnURL=https $\% 3 \mathrm{~A} \% 2 \mathrm{~F} \% 2 \mathrm{Fwww}$. clinicalkey.com $\% 2 \mathrm{Fcontent} \% 2$ FplayBy\%2Fdoi\%2F\%3Fv\%3D10.1016\%2Fj.amjcard.2020.04.054\%0Ahttps://doi.or g/10.1016/j.amjcard.2020.04.054

Alharbi, Y., Alqahtani, A., Albalawi, O., \& Bakouri, M. (2020). Epidemiological Modeling of COVID-19 in Saudi Arabia: Spread projection, awareness, and impact of $\begin{array}{llll}\text { treatment. } & \text { Applied } & \text { Sciences } & \text { (Switzerland), }\end{array}$ https://doi.org/10.3390/app10175895

Bai, Y., Yao, L., Wei, T., Tian, F., Jin, D. Y., Chen, L., \& Wang, M. (2020). Presumed Asymptomatic Carrier Transmission of COVID-19. In JAMA - Journal of the American Medical Association (Vol. 323, Issue 14, pp. 1406-1407). https://doi.org/10.1001/jama.2020.2565

Chan, J. F. W., Yuan, S., Kok, K. H., To, K. K. W., Chu, H., Yang, J., Xing, F., Liu, J., Yip, C. C. Y., Poon, R. W. S., Tsoi, H. W., Lo, S. K. F., Chan, K. H., Poon, V. K. M., Chan, W. M., Ip, J. D., Cai, J. P., Cheng, V. C. C., Chen, H., \& Yuen, K. Y. (2020). A Familial Cluster of Pneumonia Associated with the 2019 Novel Coronavirus Indicating Person-to-Person Transmission: A Study of a Family Cluster. The Lancet, 395(10223), 514-523. https://doi.org/10.1016/S0140-6736(20)30154-9 
Docherty, A. B., Harrison, E. M., Green, C. A., Hardwick, H. E., Pius, R., Norman, L., Holden, K. A., Read, J. M., Dondelinger, F., Carson, G., Merson, L., Lee, J., Plotkin, D., Sigfrid, L., Halpin, S., Jackson, C., Gamble, C., Horby, P. W., Nguyen-Van-Tam, J. S., \& Semple, M. G. (2020). Features of 16,749 Hospitalised UK Patients with COVID-19 using the ISARIC WHO Clinical Characterisation Protocol. medRxiv, 2020.04.23.20076042. https://doi.org/10.1101/2020.04.23.20076042

Fang, Y., Zhang, H., Xie, J., Lin, M., Ying, L., Pang, P., \& Ji, W. (2020). Sensitivity of Chest CT for COVID-19: Comparison to RT-PCR. Radiology, 200432. https://doi.org/10.1148/radiol.2020200432

Gorbalenya, A. E., Baker, S. C., Baric, R. S., Groot, R. J. De, Gulyaeva, A. A., Haagmans, B. L., Lauber, C., \& Leontovich, A. M. (2020). Severe Acute Respiratory SyndromeRelated Coronavirus: The Species and Its Viruses - A Statement of the Coronavirus Study Group. Biorxiv (Cold Spring Harbor Laboratory), 1-15. https://doi.org/10.1101/2020.02.07.937862

Han, Y., \& Yang, H. (2020). The Transmission and Diagnosis of 2019 Novel Coronavirus Infection Disease (COVID-19): A Chinese Perspective. Journal of Medical Virology, 92(6), 639-644. https://doi.org/10.1002/jmv.25749

Ji, W., Wang, W., Zhao, X., Zai, J., \& Li, X. (2020). Cross-Species Transmission of the Newly Identified Coronavirus 2019-nCoV. Journal of Medical Virology, 92(4), 433440. https://doi.org/10.1002/jmv.25682

Longato, E., Fadini, G. P., Sparacino, G., Gubian, L., \& Di Camillo, B. (2020). Prediction of Cardiovascular Complications in Diabetes from Pharmacy Administrative Claims. 20th IEEE Mediterranean Electrotechnical Conference, Melecon 2020 - Proceedings, 315-320. https://doi.org/10.1109/MELECON48756.2020.9140600

Mantovani, A., Byrne, C. D., Zheng, M. H., \& Targher, G. (2020). Diabetes as a Risk Factor for Greater COVID-19 Severity and in-Hospital Death: A Meta-Analysis of Observational Studies. Nutrition, Metabolism and Cardiovascular Diseases, 30(8), 1236-1248. https://doi.org/10.1016/j.numecd.2020.05.014

Moana, N. (2020). Konsep Isolasi dalam Jaringan Sosial untuk Meminimalisasi Efek Contagious (Kasus Penyebaran Virus Corona di Indonesia). Jurnal Sosial Humaniora Terapan, 2(2), 117-125. https://doi.org/10.7454/jsht.v2i2.86

Setiawan, A. R. (2020). Lembar Kegiatan Literasi Saintifik untuk Pembelajaran Jarak Jauh Topik Penyakit Coronavirus 2019 (COVID-19). Edukatif: Jurnal Ilmu Pendidikan, 2(1), 28-37. https://doi.org/10.31004/edukatif.v2i1.80

The Lancet. (2020). The Gendered Dimensions of COVID-19. In The Lancet (Vol. 395, Issue 10231, p. 1168). https://doi.org/10.1016/S0140-6736(20)30823-0

Wang, B., Li, R., Lu, Z., \& Huang, Y. (2020). Does Comorbidity Increase the Risk of Patients with Covid-19: Evidence from Meta-Analysis. Aging, 12(7), 6049-6057. https://doi.org/10.18632/aging.103000

Wenham, C., Smith, J., \& Morgan, R. (2020). COVID-19: the Gendered Impacts of the Outbreak. In The Lancet (Vol. 395, Issue 10227, pp. 846-848). https://doi.org/10.1016/S0140-6736(20)30526-2

Yang, W., \& Yan, F. (2020). Patients with RT-PCR-Confirmed COVID-19 and Normal Chest CT. Radiology, 41(1), 43-43. https://doi.org/10.1177/030802267804100122 
Zhou, F., Yu, T., Du, R., Fan, G., Liu, Y., Liu, Z., Xiang, J., Wang, Y., Song, B., Gu, X., Guan, L., Wei, Y., Li, H., Wu, X., Xu, J., Tu, S., Zhang, Y., Chen, H., \& Cao, B. (2020). Clinical Course and Risk Factors for Mortality of Adult Inpatients with COVID-19 in Wuhan, China: a retrospective cohort study. The Lancet, 395(10229), 1054-1062. https://doi.org/10.1016/S0140-6736(20)30566-3

Zhu, N., Zhang, D., Wang, W., Li, X., Yang, B., Song, J., Zhao, X., Huang, B., Shi, W., Lu, R., Niu, P., Zhan, F., Ma, X., Wang, D., Xu, W., Wu, G., Gao, G. F., \& Tan, W. (2020). A Novel Coronavirus from Patients with Pneumonia in China, 2019. New England Journal of Medicine, 382(8), 727-733. https://doi.org/10.1056/NEJMoa2001017

Zulva, T. N. I. (2019). Covid-19 Dan Kecenderungan Psikosomatis. Journal of Chemical Information and Modeling, 53(9), 1689-1699 